\title{
Análisis de los riesgos musculoesqueléticos asociados a los trabajos de ferrallas. Buenas prácticas
}

\section{Musculloskeletal risks analysis related to steel reinforcement works. Good practices}

\author{
Mónica López Alonso*1, Ma Dolores Martínez Aires*, Esther Martín González* \\ * Universidad de Granada, Granada. ESPAÑA \\ Fecha de recepción: 01/ 07/ 2011 \\ Fecha de aceptación: 01/ 09/ 2011 \\ Resumen \\ PAG. 284 - 298
}

\begin{abstract}
Los problemas musculo-esquelético suponen un $45 \%$ de las lesiones profesionales. Concretamente, los trabajadores que trabajan en las distintas actividades relacionadas con la producción y puesta en obra de la ferralla están expuestos a una gran cantidad de riesgos musculoesqueleticos. En este trabajo, se revisan detalladamente los riesgos ergonómicos de tipo físico de los ferrallistas. Este estudio permite comprobar que la normativa española en vigor desde 1997 (trasposición de la Directiva Europea sobre Seguridad y Salud en obras de construcción), no está corrigiendo los múltiples factores de riesgo musculoesqueléticos de estos trabajadores. Se propone para el análisis de dichos riesgos musculo-esqueléticos, la utilización de diversas metodologías ergonómicas. Una es el método Instituto Nacional de Seguridad e Higiene en el Trabajo para el estudio de la manipulación de cargas y, por otro lado, el método ERGO/ IBV desarrollado por el Instituto de Biomecánica de Valencia para el análisis de las posturas de movimientos repetitivos. El uso de dichas herramientas, permitirán el diseño de nuevos métodos de trabajo que disminuyan los riesgos analizados. Posteriormente, tras la identificación del elevado número de riesgos muculoesqueléticos, se definen una serie de BUENAS PRÁCTICAS para estos trabajadores expuestos a unas condiciones de trabajos muy exigentes y con escasa cultura preventiva.
\end{abstract}

Palabras Clave: Ergonomía, riesgos musculosesqueléticos, ferrallista

Abstract

The MSD -musculoskeletal disorders- represent $45 \%$ of labour injuries. Specifically, construction workers involved in the different activities linked to steel reinforcement for an insitu concrete are exposed to a high rate of such injuries. This paper reviews in detail the physical risks of the iron worker, installing steel reinforcement for an insitu concrete pour. This study has revealed that the Spanish legislation, enforced since 1997 (transposing the European Directive on the implementation of minimum safety and health requirements at temporary or mobile construction sites) is not correcting the multiple musculoskeletal risk factors of these workers. It's proposed for the analysis of such risks musculoskeletal, the use of different ergonomic methodologies. In one hand, the load handling guide from the Spanish National Health and Safety Institute, and in the other, the method ERGO/ IBV, developed by the Biomecanics Institute of Valencia for the repetitive tasks analysis. The use of these tools allows the design of new working methods that reduce the risks discussed. Subsequently, after the identification of the large number of risks musculoskeletals, it's defined a set of better practices for these workers, exposed to very demanding work conditions and with low culture of prevention.

Keywords: Ergonomics, musculoskeletal Risk, steel reinforcement worker

\section{Justificación}

\footnotetext{
1 Autor de correspondencia / Corresponding author:

E-mail: mlopeza@ugr.es
}

\section{Justification}

According to Eurostat (European Commission 2011), in the EU15 (Austria, Belgium, Denmark, Finland, France, Germany, Great Britain, Greece, Ireland, Italy, Luxembourg, Netherlands, Portugal, Spain and Sweden), Spain is the head of accidents with more than 3 days lost in the construction sector 2006 . 
In 2009, according to data from the Spanish National Statistics Institute (INE, 2011), in this sector occurred a total of 129,234 accidents with sick leave.

Latest data provided by OSHA (OSHA, 2011) indicate that workers in the construction sector have increased exposure to biological, chemical, muscle skeletal, as well as noise and temperature changes; $45 \%$ of workers say their work affects their health. Similarly, the data indicate that back musculoskeletal disorders, in the long run produce permanent damage to these workers in a percentage between $60 \%$ and $90 \%$ while in the day to day, it is between $15 \%$ and $42 \%$.

In Spain, as deduced from the VI National Survey on Working Conditions (INSHT, 2007), construction presents a higher prevalence of musculoskeletal disorders that global sectors $\mathbf{( 3 . 1 6 0}$ compared to 2.650 per 100.000 workers), being the sector in which there is a $47.5 \%$ of the risks related with musculoskeletal problems associated with effort, posture or movement.

The significance of the risks inherent to the absence of good habits to adopt the proper body mechanics, implementing suitable ergonomic strategy in the construction sector is growing (Ferreras R., C. Piedrabuena 2007) given that physical overexertion is the leading cause of accidents with loss in the sector (over $25 \%$ of all accidents), followed at some distance from those caused by blows with blunt objects or tools, and falls.

According to OSHA (OSHA, 2000, OSHA, 2004), the risks associated with inadequate mechanical body postures have their origin in the application of brute force at work, the repetition of tasks, positions, whether forced or static, rapid movements, contact compression or tension, vibration and cold temperatures. This paper discusses these risks, specifically in the case of steel reinforcement workers and the musculoskeletal disorders caused.

\section{General causes of ergonomic problems in the construction sector}

As derived from the VI National Survey on Working Conditions (INSHT, 2007), in the construction sector the main psychosocial risk is given by the need of permanence in a high or very high degree of attention, 
as required by the tasks developed by $70.5 \%$ of the workers. In addition to this risk should be noted that, in percentages very important, workers are frequently exposed to risk caused by the lack of proper ergonomics strategy in their work performance such as highly repetitive and very short tasks $(\mathbf{4 7 . 8 \% )}$, the need to work very fast $\mathbf{( 4 5 . 6 \% )}$ or tight or very short deadlines $(38.1 \%)$ and dealing with clients (the $36.3 \%$ ).

The problems associated with lack of appropriate ergonomic conditions at work are becoming increasingly important. An increase in the number of musculoskeletal disorders among such workers is being produced, associated mainly to inadequate ergonomic conditions. According to Attwood (Attwood et al. 2004) a musculoskeletal disorder involves damage to bones, muscles and other parts of the body related to the joint tissues. According to Piedrabuena et al., (Piedrabuena et al. 2005), musculoskeletal injuries are those that affect muscles, tendons, bones, ligaments and intervertebral discs.

Table 1 shows the distribution of musculoskeletal ailments in workers of the construction sector according to the VI National Survey of Working Conditions (INSHT). Likewise, Table 2 shows the factors that are commonly associated to ergonomic problems in the construction sector in Spain.

Tabla 1. Dolencias musculo esqueléticas (INSHT, 2007)

Table 1. Musculoskeletal diseases (INSHT, 2007)

\begin{tabular}{|c|c||}
\hline Zona afectada/Affected area & Frecuencia(\%)/Frecuency \\
\hline $\begin{array}{c}\text { Bajo espalda } \\
\text { Low back }\end{array}$ & 46.3 \\
\hline $\begin{array}{c}\text { Nuca/cuello } \\
\text { Nape/neck }\end{array}$ & 23.6 \\
\hline $\begin{array}{c}\text { Alto espalda } \\
\text { High back }\end{array}$ & 27.1 \\
\hline $\begin{array}{c}\text { Brazos/Antebrazos } \\
\text { Arms/forearms }\end{array}$ & 18.9 \\
\hline $\begin{array}{c}\text { Piernas } \\
\text { Legs }\end{array}$ & 12 \\
\hline $\begin{array}{c}\text { Hombros } \\
\text { Shoulders } \\
\text { NINGUNA } \\
\text { NOTHING }\end{array}$ & 11.4 \\
\hline
\end{tabular}


Tabla 2. Demandas físicas de trabajo según rama de actividad (INSHT, 2007)

Table 2. Working physical demands according to activity branch (INSHT. 2007)

\begin{tabular}{||l|c||}
\hline $\begin{array}{l}\text { DEMANDAS FíSICAS DE TRABAJO SEGÚN RAMA DE ACTIVIDAD } \\
\text { WORKING PHYSICAL DEMANDS ACCORDING TO ACTIVITY BRANCH }\end{array}$ & $\%$ \\
\hline $\begin{array}{l}\text { Adoptar posturas dolorosas o fatigantes } \\
\text { Adopting painful or exhausting postures }\end{array}$ & 50.5 \\
\hline $\begin{array}{l}\text { Levantar o mover personas u otras cargas pesadas } \\
\text { Holding up or moving people or other heavy loads }\end{array}$ & 39.5 \\
\hline $\begin{array}{l}\text { Realizar una fuerza importante } \\
\text { Applying a considerable force }\end{array}$ & 42.4 \\
\hline $\begin{array}{l}\text { Mantener una misma postura } \\
\text { Keeping the same posture }\end{array}$ & $\mathbf{5 4 . 4}$ \\
\hline Realizar movimientos repetitivos de manos o brazos \\
Executing repetitive movements with hands or arms
\end{tabular}

The most influential factors in musculoskeletal problems include age, duration of employment contract, time of the accident, company size and day of week (Burdorf et al. 2007), although other factors exist (INSHT, 2003; Piedra et al. 2005) such as:

1.- Environmental conditions in the workplace. Environmental conditions of the workplace, in particular temperature and air velocity, humidity and radiation, along with the "intensity" or the work activity level and clothing used, can lead to risky situations for the health of workers, known as temperature stress either by heat or cold.

2.- Tools and equipment management. Several factors can affect health and work efficiency when using hand tools: time-use tool, awkward postures for handling, the weight of the tool vibration and repeatability.

3.- Machinery management. Workers who handle heavy machinery on irregular land are likely to have problems in the lower part of their back. Continuous vibration and leaps as well as bounds in the seat can compress and damage intervertebral disc and back joints. 
4.- Loads manual handling. The manipulation of materials includes several stages that involve a high effort to reach the load through bending or kneeling, lifting the load, transferring the weight of the object to a load position and, finally, transport the load to the desired location.

5.- Order and cleanliness in the workplace. Keep the work area neat is pretty complex in the construction sector, as the movement of materials and the generation of residues are very frequent Obstacles in the work area can cause slips or setbacks, disordered areas may prevent the use of trolleys and lack of order in the workplace increases ergonomic hazards.

6.- Psychosocial risks. Workers may respond differently to an unexpected event, and these responses can trigger pathophysiological mechanisms of a disease (Díaz D.L., 2011).

\section{Analysis methods}

One can distinguish two large groups of musculoskeletal disorders according to the affected body area: back injuries, mainly in the lower back zone and upper limb injuries as well as neck and shoulders.

The main cause of back disorders, especially in the lumbar segments of the spine and associated muscles and ligaments, are the manual activities upon handling loads. However, most of these diseases are not caused by accidents or unique or isolated attacks, but as a result of repeated small injuries. Some simple, repetitive movements, such as grabbing, pushing or reach-tasks are repeated in the construction sector up to 25,000 times a day (INSHT, 2009).

The ergonomic analysis often used several methods, the end result being a combination of the results of various tests. In the first phase, the experimental information is collected through manuals, articles, previous studies on the subject and other available documents. Once this process has been done, the method(s) that best meet the objectives of the study in accordance with available resources, time, population size, etc.. is choosed. 
Ergonomic evaluation methods, based on the classification criteria of Buck Lehto (Lehto B., 2008), are physical, quantitative, and mixed with a component of objectivity and subjectivity (as they are based on subjective observations of objects to be scored according to predefined tables). For example, the estimate of the position through observation is a subjective method as previous studies have shown different degrees of validity and reliability, providing little information about the conditions necessary to achieve acceptable reliability (Bao et al., 2009).

In the case of risk assessment and prevention of disorders that cause skeletal muscles associated with repetitive tasks can be applied, at the present moment, different methods (see Table 3). The practical application of these methods is based primarily on gathering information on various risk factors such as the repeatability of upper limb movements, the positions taken by the arms, neck, wrists and hands, or duration of exposure to different positions/jobs.

Tabla 3. Principales métodos de evaluación ergonómica. Elaboración propia

Table 3. Main methods of ergonomic evaluation. Own elaboration

\begin{tabular}{|c|c|c|c|}
\hline MÉTODO/METHOD & OBJETIVO/OBJECTIVE & ESTUDIO/STUDY & DESARROLLADO/DEVELOPED BY \\
\hline INSHT (INSHT, 2003) & $\begin{array}{l}\text { Facilitar el cumplimiento del Real Decreto 487/1997- } \\
\text { España } \\
\text { To facilitate the compliance of Royal Decree 487/1997- } \\
\text { Spain }\end{array}$ & $\begin{array}{l}\text { Manipulación de cargas } \\
\text { Loads handling }\end{array}$ & INSHT \\
\hline $\begin{array}{l}\text { ERGO/IBV (Instituto Biomecánica } \\
\text { de Valencia, 2011) } \\
\text { ERGO/IBV Bio-Mechanical } \\
\text { Institute of Valencia, 2011) }\end{array}$ & $\begin{array}{l}\text { Analizar las posturas adoptadas en el desarrollo } \\
\text { movimientos repetitivos en la zona cuello-hombro y } \\
\text { mano-muñeca.(García-Molina et al.2000) } \\
\text { To analyze adopted postures during repetitive } \\
\text { movements in the neck-shoulder area and hand-wrist } \\
\text { area. (García-Molina et al. 2000) }\end{array}$ & $\begin{array}{l}\text { Movimientos repetitivos } \\
\text { Repetitive movements }\end{array}$ & $\begin{array}{l}\text { INSTITUTO BIOMECÁNICA DE } \\
\text { VALENCIA } \\
\text { BIO-MECHANICAL INSTITUTE OF } \\
\text { VALENCIA }\end{array}$ \\
\hline RULA (McAtamney, N., 1993) & $\begin{array}{l}\text { Observar la actividad del trabajador durante varios } \\
\text { ciclos de trabajo } \\
\text { To look up the worker activity during various working } \\
\text { cycles }\end{array}$ & $\begin{array}{l}\text { Carga Postural } \\
\text { Postural loading }\end{array}$ & $\begin{array}{l}\text { Institute for Occupational } \\
\text { Ergonomics. Universidad de } \\
\text { Nottingham }\end{array}$ \\
\hline STRAIN INDEX (Moore G., 1998) & $\begin{array}{l}\text { Valorar los esfuerzos sobre las extremidades superiores } \\
\text { de la tarea, así como el esfuerzo psíquico derivado } \\
\text { de su realización } \\
\text { To assess efforts made by legs as well as psychical } \\
\text { effort derived from the task execution }\end{array}$ & $\begin{array}{l}\text { Movimientos repetitivos } \\
\text { Repetitive movements }\end{array}$ & Medical College of Wisconsin \\
\hline OCRA (Colombini et al., 2002) & $\begin{array}{l}\text { Analizar trastornos, de tipo músculo-esquelético (TME) } \\
\text { derivados de una actividad repetitiva } \\
\text { To analyze disorders of muscular-skeletal type (MST) } \\
\text { derived from a repetitive activity }\end{array}$ & $\begin{array}{l}\text { Movimientos repetitivos } \\
\text { Repetitive movements }\end{array}$ & $\begin{array}{l}\text { Colombini D., Occhipinti E., Grieco } \\
\text { A }\end{array}$ \\
\hline REBA (Hignett Mc., 2000) & $\begin{array}{l}\text { Analizar conjuntamente las posiciones adoptadas por } \\
\text { los miembros superiores del cuerpo (brazo, antebrazo, } \\
\text { muñeca), del tronco, del cuello y de las piernas } \\
\text { To jointly analyze postures adopted by upper limbs } \\
\text { (arm, forearm, wrist), trunk, neck and legs }\end{array}$ & $\begin{array}{l}\text { Manipulación de cargas } \\
\text { Loads handling }\end{array}$ & Sue Hignett y Lynn McAtamney \\
\hline
\end{tabular}




\section{Effects on workers}

The effects on the worker that has each of the risks from inadequate ergonomic strategy (see Table 2) are the following:

1.- The extreme positions of the spine and joints (eg, push-ups and twists) done at work is detrimental to the back, neck, arms and legs, especially if sustained for a long time or performed repeatedly. Body postures very common in the construction sector (Piedrabuena et al., 2005).

2.- As for heavy loads several studies claim that about $\mathbf{2 0} \%$ of all injuries at workplace are back injuries, and nearly $30 \%$ are due to overexertion. These data provide an idea of the importance of correct evaluation of tasks involving lifting loads and proper maintenance of jobs involved (Waters et al., 1994).

3.- The injuries caused by handling of loads correspond to a high percentage (about $20 \%$ of total), being the most common injury the ones of skeletal muscle type, particularly those affecting the back.

4.- Injuries from heavy lifting may originate as a result of inadequate ergonomic conditions for handling loads (unstable loads, inadequate clamping, ...), slippery due to the characteristics of the worker who performs it (lack of information about the ideal conditions for lifting, improper outfit, etc.) or by excessive weight lifting. All aspects gathered by the method (INSHT, 2003).

5.- Environmental conditions of the job: the days of physical labor, as well as outdoor work situations can lead to muscle fatigue and thermal stress.

Figure 1 shows how a large percentage of workers in the construction sector have discomfort in their lower back zone. 


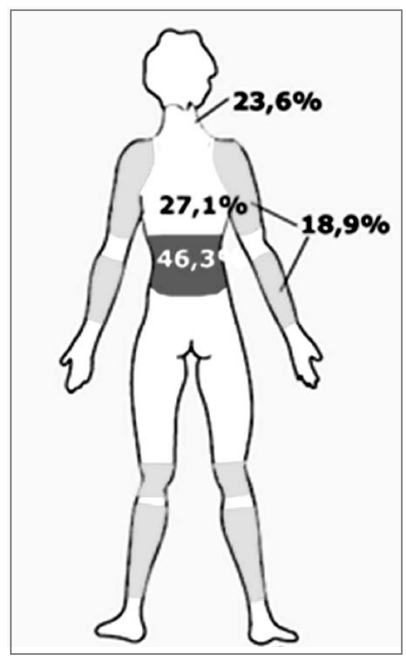

Figura 1. Distribución de las molestias musculoesqueleticas en los trabajadores de la construcción (INSHT, 2007) Figure 1. Distribution of slight muscular-skeletal pains undergone by construction workers. (INSHT. 2007)

\section{Brief ergonomic analysis of steel reinforcement workers job}

In Spain, according to Real Decreto 2010/1996, the main tasks of steel reinforcement workers are:

- To prepare materials with the conditions of shape, length and geometric characteristics suited to each armor.

- To build armor in the workshop, which involves measuring, cutting and bending steel bars, as needed.

- To install and assemble on site the armor built at the workshop and other made-in site for its subsequent concreting.

- To organize steel storage (wires, rods, mesh and molded parts) and control the quality of these materials.

What kind of problems arise from an improper ergonomics strategy at work, at steel reinforcement jobs?

Skeletal muscle risk factors at steel reinforcement jobs

Table 4 shows, schematically, a summary of the various risk factors derived from skeletal muscles with an improper body mechanics developed in the construction activities or procedures that are performed on steel reinforcement jobs. 
Tabla 4. Riesgos musculo esqueléticos según las principales actividades desarrolladas en la fase de ferralla (Instituto Navarro de Seguridad Laboral, 2008)

Table 4. Muscular-skeletal risks according to main tasks developed during reinforcement matting stage (Instituto Navarro de Seguridad Laboral, 2008)

\begin{tabular}{|c|c|c|}
\hline RIESGO/RISK & DESCRIPCIÓN/DESCRIPTION & ACTIVIDAD/FASE/STAGE ACTIVITIES \\
\hline $\begin{array}{l}\text { 1.-Posturas forzadas de tronco y brazos } \\
\text { 1.Forced trunk and arms postures }\end{array}$ & $\begin{array}{l}\text { Trabajos a ras del suelo o por encima del nivel de los } \\
\text { hombros y con el cuello hacia atrás. } \\
\text { Work executed at the ground level or above shoulders } \\
\text { level keeping the neck tilted back }\end{array}$ & $\begin{array}{l}\text { Colocación y amarre de ferralla..Estructura y forjado. } \\
\text { Losa de cimentación. Figura } 2 a \text {. } \\
\text { Reinforcement arrangement and tying up. Structure } \\
\text { and framework. Footing slab. Figure } 2 a \text {. }\end{array}$ \\
\hline $\begin{array}{l}\text { 2.-Manipulación manual de cargas } \\
\text { 2.Manual load handling }\end{array}$ & $\begin{array}{l}\text { Manipulación, levantamiento desde el suelo y transporte } \\
\text { sobre los hombros, de barras de metal pesadas (15 Kg. } \\
\text { de media, aproximadamente). } \\
\text { Handling. Lifting load from the ground and transporting } \\
\text { it on the shoulders. Heavy metal bars ( } 15 \mathrm{~kg} \text { average } \\
\text { app.) }\end{array}$ & $\begin{array}{l}\text { Transporte y colocación de las armaduras. Figura } \\
\text { 2b. } \\
\text { Reinforcement transportation and arrangement. } \\
\text { Figure } 2 \text { b. }\end{array}$ \\
\hline $\begin{array}{l}\text { 3-4.-Fuerza, repetitividad y posturas forzadas } \\
\text { en la muñeca asociadas al uso de } \\
\text { herramientas manuales } \\
\text { 3.4. Strength, repetitiveness and forced } \\
\text { postures made by wrists which are associated } \\
\text { to the use of hand-tools. }\end{array}$ & $\begin{array}{l}\text { Repetición del giro y la flexión extrema de las muñecas } \\
\text { cuando se ata el alambre a las barras, unida a posturas } \\
\text { de flexión e inclinación lateral de la espalda y los brazos. } \\
\text { Repetitive turn and extreme inflection of wrists when } \\
\text { wire is tied up to the bars, as well as inflection and } \\
\text { lateral inclination postures of back and arms. }\end{array}$ & $\begin{array}{l}\text { El atado de bridas de las armaduras y hormigonado: } \\
\text { Cimentación zapatas y zunchos; estructura forjados } \\
\text { Losa de cimentación. Figura 2c. } \\
\text { Tying up of bridles of reinforcement and reinforced } \\
\text { concrete. Footing and drive-bands: brick structures } \\
\text { Footing slab. Figure 2c }\end{array}$ \\
\hline $\begin{array}{l}\text { 5.-Trabajo sobre superficies inestables e } \\
\text { irregulares } \\
\text { 5.Work developed on irregular or unsteady } \\
\text { surfaces }\end{array}$ & $\begin{array}{l}\text { Manejar o transportar material a través de suelos } \\
\text { irregulares o llenos de obstáculos } \\
\text { Handling or transporting material through irregular and } \\
\text { obstructed grounds. }\end{array}$ & $\begin{array}{l}\text { Traslados por las distintas zonas de la ferralla. Figura } \\
\text { 2d. } \\
\text { Moving through different reinforcement mat areas. } \\
\text { Figure 2d }\end{array}$ \\
\hline
\end{tabular}
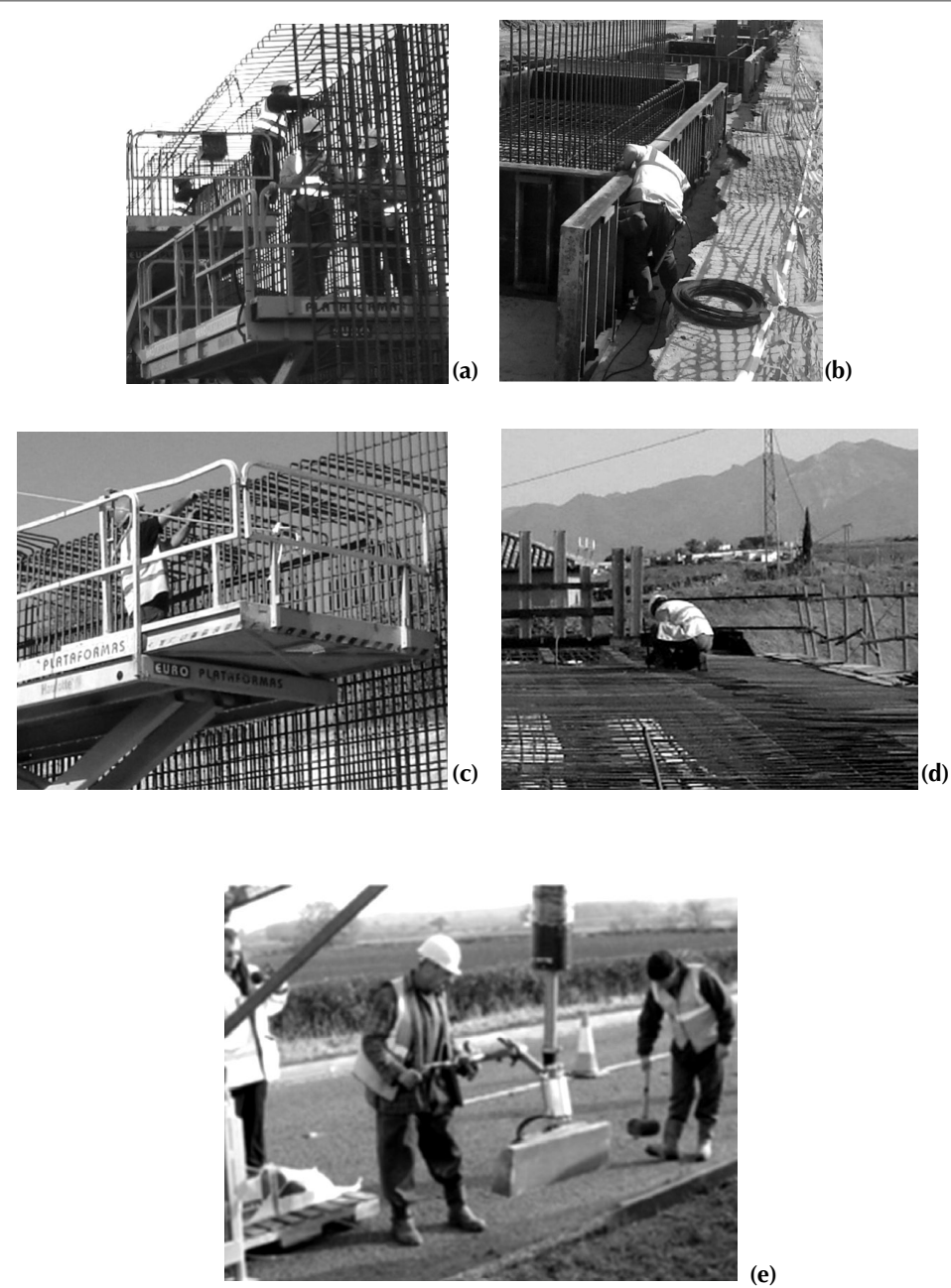

(e)

Figura 2. Puesta en obra de bordillos (Bust et al., 2005)

Figure 2. Laying of curbs (Bust et al., 2005) 


\section{Good practices}

From the data provided by the VI National Survey on Working Conditions good practices are also deduced in the construction sector:

$1^{\circ}$ In more than $50 \%$ of the cases, measures were taken in order to improve working conditions aimed to reduce the risks of musculoskeletal disorders.

$2 \circ$ Only $21.7 \%$ of the cases decided to introduce changes in working methods.

$3^{\circ}$ In more than $30 \%$ of the cases, measures taken only made changes in the machinery and equipment, without addressing the underlying causes of workplace design, as has been said before, are those that give rise to more risk and more difficult to change because, in most cases, are part of the habit of work.

In addition to the above, there is progress in the industrialization of the construction sector and the design of mechanisms, which among other benefits, prevent musculoskeletal risks to the worker (see Figure $2 \mathrm{~d}$ and 3 ) which must be considered as good practices. In the field of steel rods, the use of prefabricated reinforcement is increasingly common, and not only in welded steel mesh (see Figure 4).

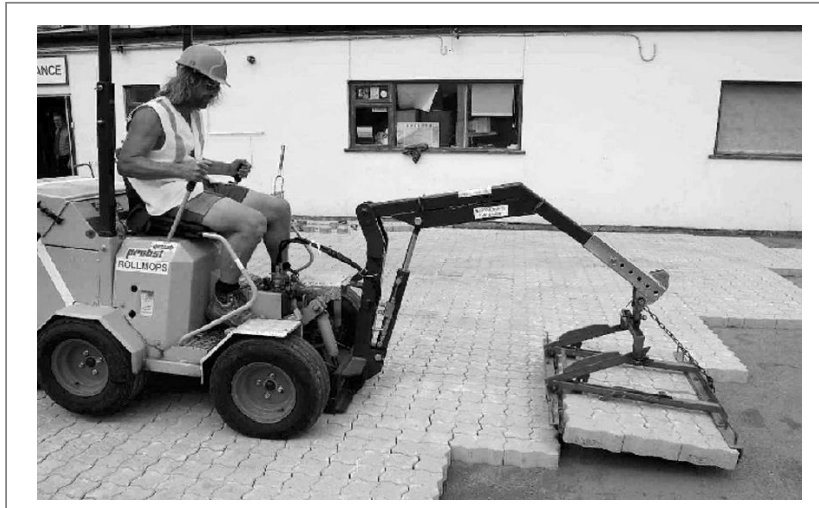

www.paving.org.uk

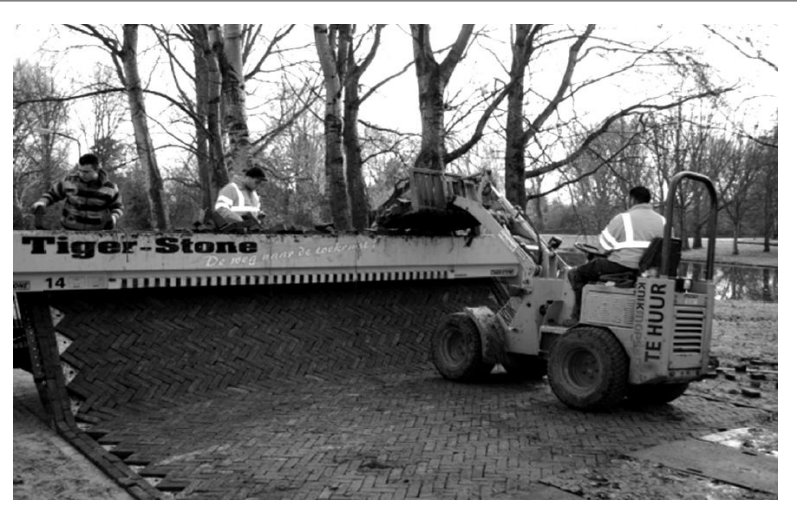

http://www.tiger-stone.nl

Figura 3. Distintos sistemas de colocación de adoquines

Figure 3. Different systems for cobblestones placement 


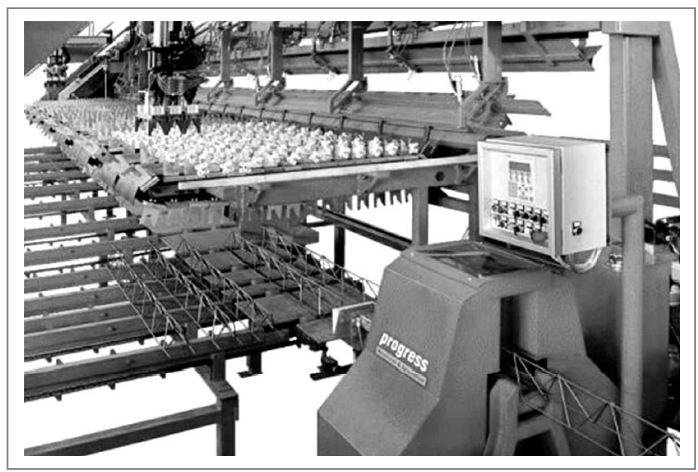

Figura 4. Ferralla prefabricada http://www.progress-m.com Figure 4. Pre-fabricated reinforcement mat

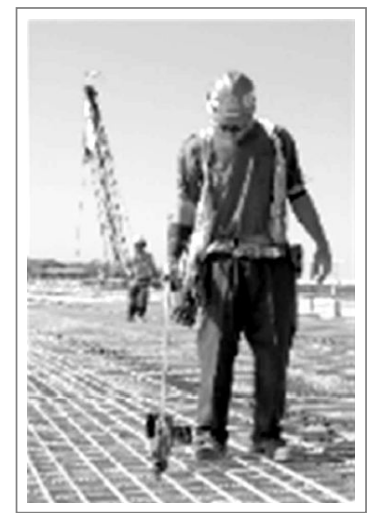

Figura 5. Herramienta para atar barras de refuerzo con mango de extensión (Albers E., 2007)

Figure 5. Tools for tying up reinforcement bars, with extension handle (Albers E., 2007)

Finally, it should be presented a series of good practices to prevent or reduce musculoskeletal risks steel reinforcement workers described in the previous section. In general, the phase of selection and purchase of steel rods products, must provide the purchase of materials in such ways that are acquired as needed, that is, trying to reduce the stored material. This eliminates the need to maneuver and to make unnecessary movements around the materials.

Forced postures of trunk and arms

- Use aids that maintain an adequate level of work. In work at ground level, bend the legs and crouch, avoiding keeping the legs straight, then bend the back.

- Use of fixing tools that reduce crouched positions and tools to tie reinforced bars and rods (see Figure 7).

- The use of platforms to support columns and other components can reduce back flexion. 
Manual handling of loads

- Handle the loads close to the body, at a height between the elbows and knuckles to reduce tension in the lumbar region and avoid having to make unnecessary handling (see Figure 6).

- While analyzing the load prior to lifting it, make a "lifting plan" (shape and size, weight, grip areas, potential danger points, stability, etc..) If materials weigh more than $25 \mathrm{~kg}$, they should not be lifted by one person, it is necessary to use mechanical aids or seek the help of another worker.

- Separate the feet to provide a stable and balanced position for lifting.

- Bend the legs at all times keeping the back straight.

- Stretching and warm up before and after work and during breaks to be made when working long time in an awkward position.

- Place materials as close as possible to the work area. This reduces transport distances of the same.

- Estimate the rotation of the trunk in determining the angle formed by lines connecting the heel to the shoulder line (see Figure 6). Whenever possible, tasks should be designed so that the loads are handled without making turns. The turns of the trunk increases the compressive forces in the lumbar area.

- Activity tied to the knees, we recommend alternating positions of the sword inclined squatting and kneeling positions.

- The bars can be lifted from the ground more easily when placed on support platforms. Try that the bars are stored in specific shelves and at waist level.

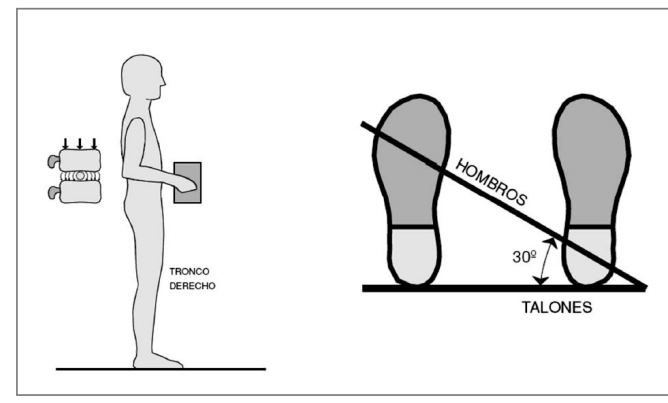

Figura 6. Postura y posición adecuada (INSHT, 2003)

Figure 6. Posture and position adequate (INSHT, 2003) 


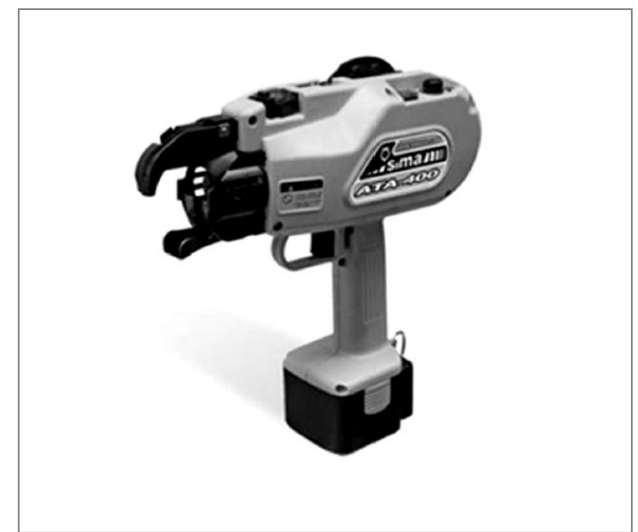

Figure 7. Herramienta eléctrica para el atado de ferralla Figure 7. Power tool for steel rods

Force, repetitive and forced postures of hand tools

- Use Ergonomic Hand Tools: with proper termination of the handle of adequate roughness and tools which push or twist exercise it may be desirable that the surface is mottled or grooves in the opposite direction to the movement.

- Use power tools instead of hand whenever possible for tying and knotting of the bars.

- Change task, perform stretching and take breaks from repetitive tasks.

- Plan job rotation positions of different types.

- When welding, push the mask up and down with the hand, avoiding sudden movement of neck to lower it.

Work over irregular and unstable surfaces - If there is no choice but to work at floor level, follow the following instructions:

. If you must work on your knees, to minimize contact stress of the knees with the surfaces of the bars, use padded knee.

. Take short breaks every 20 minutes of work with the trunk flexed. Place the back straight and stretch, take a few steps and continue working.

- Maintain a good level of fitness and flexibility.

- Sort the materials as close as possible to where they have to be placed.

- Make sure that the soil is dry and there are no obstacles. Back injuries occur mostly when the person slips or trips. 


\section{Conclusions}

Disorders resulting from poor ergonomic practices are not as obvious as accidents at work or a traffic accident while traveling. Furthermore, prevention of these risks is not as eloquent as in those in which the risk is reduced by placing a collective protection or by the use of PPE. Such risks are part of the standard technique of the employee or are problems inherent from the use of certain machines (as in the case of vibration tools handheld). It is important therefore to be aware of existing ergonomic risks the post of work and to try to avoid them.

The agents involved in the production process must observe the working methods and habits of employees and watch the ergonomic measures. Prevention of injuries musculo-skeletal at work is now one of the biggest challenges for European countries.

The activity of a steel rods has certain risk factors that may cause MSDs if not

follow adequate work habits. It is therefore important to pay attention to the positions of

work, perform repetitive movements and cargo handling, in particular the general objectives theoreticaly studied, which are:

- Try to facilitate or improve the environment of cargo transportation in this sector.

- Improve the development of tasks that require repetition during its work.

- Improving environmental working conditions so that these are not harmful to the health of workers or for the performance of their work.

\section{Referencias / References}

Albers J.T. y Estill C.F. (2007), Simple Solutions Ergonomics for Construction Workers. OSHA, 2007. Attwood D.A., Deeb J.M. y Danz-Reece M.E. (2004), Physical factors in Ergonomic Solutions for the Process Industries. Gulf Professional Publishing, Burlington, pp. 65-110, 2004.

Bao S., Howard N., Spielholz P., Silverstein B. y Polissar N. (2009), Interrater Reliability of Posture Observations. Human Factors: The Journal of the Human Factors and Ergonomics Society, vol. 51, no. 3, pp. 292-309, 2009.

Instituto Biomecánica de Valencia. (2011), Disponible en http://www.ibv.org/en/productos/ictapplications/ show_product/82/170.html?itemid=82. Acceso el 01. 07.2011.

Burdorf A., Windhorst J., van der Beek A.J., van der Molen H. y Swuste P.H.J.J. (2007), The effects of mechanised equipment on physical load among road workers and floor layers in the construction industry. International Journal of Industrial Ergonomics, vol. 37, no. 2, pp. 133-143, 2007. 
Bust, P.D., Gibb, A.G.F. \& Haslam, R.A. (2005), Manual handling of highway kerbs-focus group findings. Applied Ergonomics, vol. 36, no. 4, pp. 417-425, 2005.

Díaz D.L. (2011), Estrés laboral y sus factores de riesgo psicosocial. Revista CES Salud Pública, vol. 2(1), pp. 80-84, 2011. European Commission (2011), Disponible en: http://epp.eurostat.ec.europa.eu/portal/page/portal/statistics/search_database. Acceso el 01.07.2011

Ferreras R. A. y Piedrabuena C. A. (2007), Ergonomía en el sector de la Construcción. Revista de biomecánica, no. 47, pp. 47$53,2007$.

García-Molina C., Chirivella C., Page A., Tortosa L., Ferreras A., Moragar H. y Jorquera J. (2000), Ergo/IBV - Evaluación de riesgos laborales asociados a la carga física. Biomechanics Institute of Valencia, Valencia (Spain), 2000.

Hignett S. y McAtamney L. (2000), Rapid Entire Body Assessment (REBA). Applied Ergonomics, vol. 31, no. 2, pp. 201-205, 2000.

INE. (2011), Instituto Nacional de Estadísticas de España. Disponible en: http://www.ine.es/. Acceso el 01.0/.2011. INSHT (2003), Instituto Nacional de Seguridad e Higiene en el Trabajo. Guía técnica para la manipulación manual de cargas, Madrid (España), 2003.

INSHT (2007), Instituto Nacional de Seguridad e Higiene en el Trabajo. VI Encuesta Nacional de Condiciones de Trabajo. Madrid (España), 2007.

INSHT (2009), Instituto Nacional de Seguridad e Higiene en el Trabajo. Ficha Técnicas Tareas repetitivas: método Ergo/IBV de evaluación de riesgos ergonómicos. Madrid (España), 2009.

Instituto Navarro de Seguridad y Salud (2008), Manual de Buenas Prácticas ergonómicas en la construcción. Navarra, España, 2008.

Lehto M.R. y Buck J.R. (2008), Introduction to human factors and ergonomics for engineers, Lawrence Erlbaum, New York. McAtamney L. y Nigel Corlett E. (1993), RULA: a survey method for the investigation of work-related upper limb disorders. Applied Ergonomics, vol. 24, no. 2, pp. 91-99, 1993.

Moore J.S. y Garg A. (1998), The effectiveness of participatory ergonomics in the red meat packing industry Evaluation of a corporation. International Journal of Industrial Ergonomics, vol. 21, no. 1, pp. 47-58, 1998.

OSHA (2011), European Agency for Safety and Health at Work. Disponible en: http://osha.europa.eu/en/sector/construction. Acceso el 22/02/2011.

OSHA (2004), Ergonomics for the Prevention of Musculoskeletal Disorders. Ergonomics: The Study of Work. OSHA, 2002. Piedrabuena C. A., Ferreras R. A. y García M. C. (2005), Manual de Ergonomía en la Construcción. Fundación Laboral de la Construcción. España, 2005.

Waters T.R., Putz-Anderson V. y Garg A. (1994), Applications Manual for the Revised NIOSH Lifting Equation, pp. 94.1994. 